12. Соловйова Л.Ф. Категорія оцінки у сучасній лінгвістиці. Сучасні лінгвістичні студії : навчальний посібник. Житомир : Вид-во ЖДУ ім. І. Франка, 2015. С. 30-60.

13. Островська О.М. Лінгвостилістичні засоби реалізації категорії оцінки (на матеріалі американської художньої прози) : авторефр. дис. ... канд. фрілол. наук: 10.02.04. Львів, 2001. 20 с.

14. Яновець А.І. Прагматика засобів вираження негативної оцінки в сучасній англійській мові. Науковий вісник Волинського державного університету імені Л. Українки. 2007. Вип. 4. С. 248-252.

15. Гальперин И.Р. Текст как объект лингвистического исследования. 5-е изд. Москва : КомКнига, 2007. $144 \mathrm{C}$.

16. Виноградов В.В. Проблемы русской стилистики. Москва : Высшая школа, 1981. 320 с.

17. Ахманова О.С. Словарь лингвистических терминов. 2-е изд. Москва : УРСС ; Едиториал УРСС, 2004. $571 \mathrm{C}$.

18. Huxley A. Crome Yellow. Vintage Classics, 2009. 170 p.

19. Bronte Ch. Jane Eyre. Vintage Classics, 2016. 560 p.

20. Galsworthy J. The Forsyte Saga.. Headline Review, 2008. Book 1 : The Man of Property. 384 p.

21. Jerome K. Jerome. Three Men in a Boat. Oxford University Press, 2008. 112 p.

22. Aldington R. Death of a Hero. Penguin Classics, 2013. 344 p.

UDC 811'11

DOI https://doi.org/10.32782/tps2663-4880/2021.18.28

\title{
MALE FASHION IN THE MEDIA DISCOURSE
}

\section{ЧОЛОВІЧА МОДА В МЕДІЙНОМУ ДИСКУРСІ}

\author{
Tsapro G.Yu., \\ orcid.org/0000-0002-0748-7531
}

Candidate of Philological Sciences, Associate Professor, Associate Professor at the Department of English Language and Communication Borys Grinchenko Kyiv University

Smirnykh V.R. orcid.org/0000-0002-3956-3738

Master of Philological Sciences at the Department of English Language and Communication Borys Grinchenko Kyiv University

\begin{abstract}
The study is devoted to the research of fashion discourse concentrating mostly on male fashion and its discourse representation in Gentlemen's Quarterly and Esquire fashion articles published in 2017-2021. The gender factor seems to be crucial in the field of fashion, which is reflected through verbal masculine portrayals illustrated with photos in fashion magazines, which, on the one hand, can impose some particular looks a modern man should have, and on the other, promoting designers, fashion houses and underlying the importance of fashion and trends in people's life. The objectives of the research are to single out and classify male clothing items, cuts and colours, as well as to interpret non-verbal means, which are all together suggested for men interested in latest trends. The corpus of the most fashionable male items of clothes consists of 56 pieces, all of them being divided into basics (10 items equaling to 17,9\%) and their variants (46 items reaching 82,1\%). The research proves that some clothing pieces are more popular than others: coat and its different variants greatcoat, overcoat, pea coat, raincoat, topcoat, trench coat, waistcoat amounting to 16,1\% of all the clothing items, trousers with their variants chinos, corduroys, slacks making 17,9\%, and jacket with its variants blazer, blouson, bomber jacket, fur blouson, hooded parka, parka jacket, racer jacket, track jacket, trucker jacket, tuxedo jacket, zipper jacket comprising $25 \%$ of the items of clothes that are advertised and recommended in male magazines. The corpus of cuts of male clothing (e.g., asymmetric (coat), banded (collar), button-down (shirt), button-front (t-shirt), cable-knit (sweater), cargo (pants), flared (trousers), high-waisted (denim trousers), longline (hoodie), natural fit (suit), oversized (cardigan/coat), pleated (pants), quilted (parka), relaxed (shorts), zip-up (jacket)) consists of 49 different lexical items describing all the complexity of designers' creativity. The male colour palette is presented by 9 basic colours (black, green, grey, red, white, yellow, brown, purple, blue), the number of their hues differs much, with blue, grey and red having most hues indigo, light-blue, navy, pale-blue; dark-grey, light-grey, metallic and burgundy, maroon, russet. The image of masculinity is supported with the help of photos of strong men in men's conventional environment, though there are very few deviations published in years 2020-2021.
\end{abstract}

Key words: gender, fashion discourse, media discourse, masculinity, male clothing item. 
Розвідку присвячено дослідженню дискурсу моди, в основному увагу зосереджено на чоловічій моді, та дискурсивній репрезентації моди у статтях журналів “Gentlemen's Quarterly" та “Esquire”, опублікованих у 2017-2021 роках. Ґендерний чинник, здається, є вирішальним у сфері моди, що відображається через вербальні чоловічі зображення, проілюстровані фотографріями в модних журналах, які, з одного боку, можуть нав'язувати особливий модний образ, який повинен мати сучасний чоловік, а з іншого - просування дизайнерів, будинків моди та підкреслення важливості моди та модних трендів у житті людей. Завдання дослідження - виокремити та класифікувати предмети чоловічого одягу, їх крої та кольори, а також проінтерпретувати невербальні засоби, що пропонуються чоловікам, які цікавляться останніми тенденціями моди. Корпус наймодніших чоловічих предметів одягу складається з 56 предметів, усі вони поділені на основи (10 предметів, що дорівнює 17,9\%) та їхні варіанти (46 предметів (82,1\%)). Дослідження доводить, що деякі предмети одягу мають більшу популярність, ніж інші: coat та варіанти (greatcoat, overcoat, pea coat, raincoat, topcoat, trench coat, waistcoat) становлять 16,1\% з усіх предметів одягу, trousers із варіантами (chinos, corduroys, slacks) - 17,9\%, a jacket із варіантами (blazer, blouson, bomber jacket, fur blouson, hooded parka, parka jacket, racer jacket, track jacket, trucker jacket, tuxedo jacket, zipper jacket) становлять $25 \%$ предметів одягу, які рекламуються та рекомендуються в чоловічих журналах. Корпус кроїв чоловічого одягу (asymmetric (coat), banded (collar), button-down (shirt), button-front (t-shirt), cable-knit (sweater), cargo (pants), flared (trousers), high-waisted (denim trousers), longline (hoodie), natural fit (suit), oversized (cardigan/coat), pleated (pants), quilted (parka), relaxed (shorts), zip-up (jacket)) складається із 49 різних лексичних одиниць, що описують усю складність творчості дизайнерів. Палітра чоловічих кольорів представлена 9 основними кольорами (black, green, grey, red, white, yellow, brown, purple, blue), кількість їх відтінків дуже відрізняється, водночас кольори blue, grey та red мають більшість відтінків (indigo, light-blue, navy, pale-blue; dark-grey, light-grey, metallic та burgundy, maroon, russet). Образ маскулінності підтримується за допомогою фотографій сильних чоловіків у звичайному чоловічому середовищі, хоча у 2020-2021 роках з'являється невелика кількість фотографій, що відхиляється від традиційних образів.

Ключові слова: ґендер, дискурс моди, медійний дискурс, маскулінність, предмет чоловічого одягу.

Introduction. The research aims at analyzing fashion discourse representing fashion trends for men concentrating on the specific male clothing items, cuts, colours and images offered. The material of the study comprises 50 Gentlemen's Quarterly and Esquire magazine articles published in 2017-2021. Discourse and context analyses have been used to single out text passages and lexemes which describe or represent male clothing items, colours and cuts, comparative analysis as well as quantitative one enable to systemize and interpret obtained results.

Literature Overview. Fashion presents trends, imposes what is popular at some specific time offering clothing, footwear, hairstyle, accessories, jewelry, even style of living, on the one hand, while on the other, fashion can be seen as a field that involves industries and media to produce and advertise what is popular and to make people believe these ideas. In this way fashion influences people's choices about what to buy and what to wear. M. Jansen [1] describes fashion as desirable dress at a given moment and place whereby its desirability can be based on a wide range of values, be it social, political, nostalgic, exclusivity, modernity, innovation, nationalism, youth, etc.

According to Tjäder [2, p. 34], fashion is socially biased, as it is created for the upper class in order to unite their social group and distinguish themselves from other social groups of lower rank, the moment when the lower social classes imitate popular trends, they go out of fashion and the elite initiates a new fashion.

Fashion discourse is realized through communication, where the media actually tell all the news in the sphere of fashion. Thus, fashion discourse does not consist only of clothes and producing process, but it also includes the language that describes it, as well as visual means, which are of great importance in the whole system. R. Barthes [3] makes a distinction between the written system of fashion and the visual system of fashion stating that the visual system mostly refers to the clothing garments itself or their pictures and photographs, while the written system deals with lexis or texts which describe these clothing items and he also says [3, p. 3-4] that fashion reminds a triangle as it consists of three interdependent shifters: technological, iconic and verbal, which is respectively represented as real clothing, images and language. Fashion discourse is a complex phenomenon which is influenced by many social factors, which limit and control people's choices in clothing, thus just a little bit more than 100 years ago the situation in fashion discourse was very different compared to modern time, for example, in the 1900s men were prescribed to wear three-piece suits jacket, vest and trousers, - complimented by a hat; in 50 years' time female style changed dramatically, while the male style mostly remained the same with very few inventions such as single-breasted jacket and tapered trousers and young people wearing more eccentric garments $[4$, p. 6-8, 28-31].

'The big shift' of fashion happened in the middle of the last century and now it is hard to believe that only during the period of time of about 50 years the fashion changed completely and instead of the clothes that cover the whole body we started to wear more opened, short and way-out clothing. Although men are still seen wearing suits almost on any occasion, formal or informal: $\langle\ldots\rangle$ wear suits to summit meetings, male job applicants wear them 
to interviews, and men accused of rape and murder wear them in courts $<\ldots>$ [5].

Gender aspect is strong in fashion industry. Fashion helps to reproduce gender as a form of body style, producing a complex interplay between sexed bodies and gendered identities" [6, p. 2].

Male clothing items. Male clothing is under constant changes nowadays. The recent crucial changes are reflected in current fashion discourse and numerous peculiarities of new male clothing items that are offered for men to wear. Although the main pieces of male clothes have remained the same for some centuries, some of them have been modified greatly and have acquired new variations.

The corpus of 56 male clothing items, which were singled out from male fashion articles, has been divided into basics (shirt, trousers, sweater, etc.) and their variations which have distinctive features expressing the modification of the male basics (shirt and tuxedo shirt), which is presented in the following table (see Table 1).

The following graph (see Graph 1) presents the frequency use of male clothing items with jacket being most common and suit and T-shirt being least mentioned in the fashion discourse.

Jacket is one of the most popular items of clothing that has a vast number of varieties. In male fashion jackets can be of coarse forms and fabrics (fur blouson, hooded parka, leather jacket, racer-jacket, etc.), as well they can be related to very masculine sports or activities (bomber jacket, track jacket, trucker jacket), or represent classical style (tuxedo jacket, velvet jacket): $<\ldots>$ the woodland camo nylon coach

Male basic clothing and its varieties

\begin{tabular}{|c|l|}
\hline Basic items & \multicolumn{1}{|c|}{ Varieties of basics } \\
\hline coat & duffle coat, greatcoat, overcoat, pea coat, raincoat, topcoat, trench coat, waistcoat, wool coat \\
\hline jacket & $\begin{array}{l}\text { blazer, blouson, bomber jacket, fur blouson, hooded parka, leather jacket, parka jacket, racer jacket, } \\
\text { track jacket, trucker jacket, tuxedo jacket, velvet jacket, zipper jacket }\end{array}$ \\
\hline shirt & baseball shirt, linen shirt, shacket, tuxedo shirt \\
\hline shorts & baseball shorts, light linen shorts, linen drawstring shorts \\
\hline suit & - \\
\hline sweater & cardigan, knit, pullover, roll-neck, silk knitwear, sweatshirt \\
\hline T-shirt & - \\
\hline top & tank top, tracksuit top \\
\hline trousers & $\begin{array}{l}\text { chino trousers, corduroy pants, denim jeans, jeans, joggers, linen pants, slacks, sweatpants, washed- } \\
\text { cotton chinos }\end{array}$ \\
\hline vest & sweater-vest \\
\hline
\end{tabular}

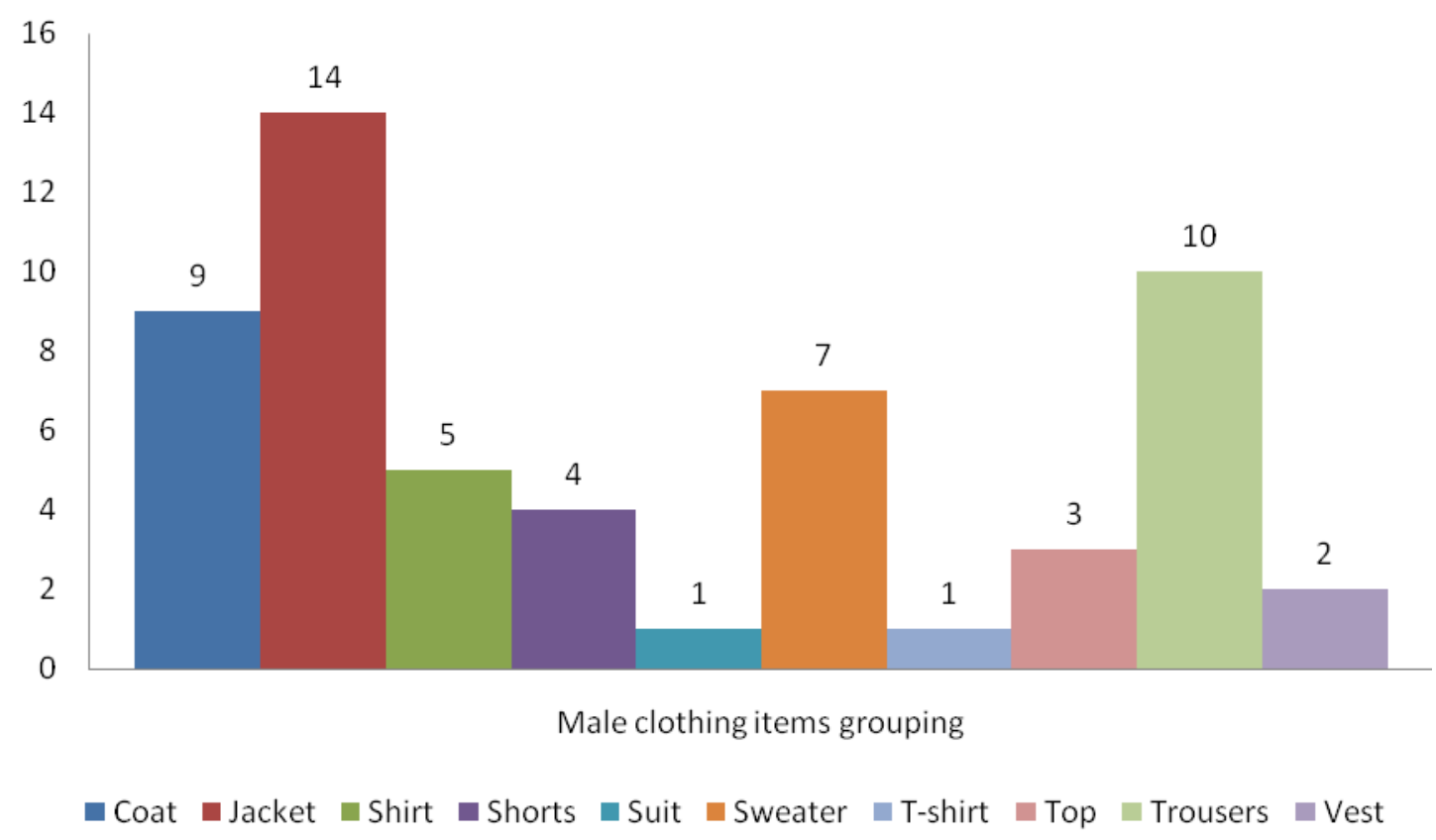

Graph 1. Male clothing items grouping 
jacket is perfect for layering up during a chilly summer's eve <... [7, p. 61].

In modern fashion discourse shirts of classical style (linen shirt, tuxedo or those that tend to the sport style (baseball shirt) are considered to be fashionable: Among our favourites is the Oxford Tailored Shirt, available in a range of plain soft spring shades including red, white and blue [8, p. 148].

A blend-version of shirt and jacket, shacket, is a new hit now: The shacket is beefier than your standard button-down but still looks very shirt-like, which means it's particularly conducive to the type of strategic layering we've all been looking forward to embracing with reckless abandon. No matter what you call it, it's the piece you should be wearing day in and day out as soon as the weather outside cools down [9].

Different variants of shorts are quite very popular nowadays in the male fashion. They tend to light style, natural fabrics and classical cuts (light linen shirts, linen drawstring shirts), or look more like a sportswear (baseball shirts): A high-function conflation of oversized ripstop windcheaters, heavy-duty hiking sandals and outdoors ready cargo shorts, the trend was manifested most clearly in durable high-fashion camping rucksacks, a bit like this beasty from Gucci [8, p. 81].

In fashion discourse suits are still considered to be a must-have in a male wardrobe: $A$ navy suit is perfect for most formal occasions and a wedding is no different-but selecting a paler shade of blue, or even stone for the more adventurous, will ensure you stand out in a sea of men who played it safe [7, p. 106]. Moreover, they are strongly recommended in the male magazines: These are, shall we say, INTERESTING TIMES. An era of bigly DISRUPTIONS. But the more the world shifts around us, the more we value the strength of a SIMPLE, IMPECCABLY CUT SUIT [10] Suits are seen as the easiest way to look perfect: $<\ldots>$ while it's perfectly easy for a preternaturally handsome Hollywood actor to look amazing in a suit (handsome + bespoke = amazing in a suit), the formula for nailing smart-casual style is much more complicated, precisely because there are so many other variables [7, p. 64].

In the modern male fashion sweaters are of coarse forms and cuts, heavy fabrics (cardigan, knit, pullover, roll-neck, or sweatshirt), and they should be expressive as well: Now that menswear has fully embraced a more-is-more mentality, we're into sweaters that make a statement-sometimes literally, in the form of Sex Pistols lettering <... $>$ [8, p. 186]. However, more softened and even female-borrowed styles are borrowed by men - silk knitwear.
Another popular piece of clothing is a T-shirt (or tee). This term appeared in the beginning of the XX century in reference to the shape of this piece of clothes. Another piece of clothing in a male wardrobe that is in trend now is top. Usually the style of this piece of clothing refers to the sport activities (tank top, track top, etc.): Effectively a catch-all term for a top - usually a T-shirt or Cuban-collared bowling shirt - teamed with a matching pair of shorts, co-ords first hit the runways at some point in 2017, with easy-access fashion brands such as $Y M C<\ldots>$ [11, p. 42].

Trousers are an inseparable part of a male wardrobe that has numerous varieties. Some of them are of casual style and usually of easy fit - chino trousers, denim jeans, linen pants, slacks, etc.: Short of sporting a perpetual suit, one of the easiest uniforms to adopt is the white shirt, jacket and trousers/jeans twinned with a decent pair of shoes [7, p. 120]. Other types tend to become a popular sport style-joggers, sweatpants: Simply put, the sweatpant has arrivedand it's here to stay [8]; But before it does, you'll need to start shopping for your new jogger pants. Start with this list, and trust your instincts [12].

Another part of a male wardrobe is vest. Throughout the centuries it preserved its initial purpose, became a part of the classical suit and even evolved into different more casual forms and cuts. Nowadays sweater vests are considered to be popular and stylish: What you could also be talking about, Robert, is a jerkin-style sweater vest, finished with a buttoned front [8, p. 151].

Coat is a comfortable piece of clothing for colder days and is often advertised as an outdoor outfit: The perfect coat for when it's cold and wet, but not freezing. Mackintosh's Cambridge overcoat is cut from dry-wax cotton, so it keeps the elements at bay, but is left unlined for maximum comfort and layering opportunities [9, p. 61].

Even if male basic clothing has not changed much, there are a couple of new elements that were introduced into fashion discourse not so long ago. Doubtlessly, the most popular items of male wardrobe that are still trendy and have a lot of variants are coats, jackets, shirts and trousers.

Cuts of male clothing in fashion discourse. Clothing cuts is another important characteristic of fashion discourse: Right now, from luxury tailoring to utilitarian chic, menswear has cast its net wide with bold cuts, rich colours and a cool humour that will see you through the season ahead [8, p. 230]. The corpus of the trendiest cuts of male items of clothing consists of 49 different shapes and forms. They are:

- shirt-athletic, button-down, embroidered detailing, extralong, long-sleeved, sleeveless, relaxed, 
slim-fit, loose, open-necked, polo, wide-collar, outsized, tailored, pussy-bow (blouse) (e.g., Sunspel's polo shirts are devoid of branding and ultralightweight, meaning they're incredibly easy-wearing in the heat and they look extra elegant [13, p. 111]);

- T-shirt-button-front, round neck, sleeveless (e.g., These Round Neck T-Shirts are a staple wardrobe piece that every man should own. Stay comfortable and stylish in the soft and breathable fabric [14]);

- collar - flap, frilly, edge-stitched, banded (e.g., Or, you can dress like those who'd never mingle with the masses in the first place in a big frilly aristocratic collar [15]);

- coat - asymmetric, oversized, double-breasted (e.g., With additional details in the mixed button cuff fastening and three pockets to the front either side of the double breast closure, the Holland Esquire coat will be an opulently classic winter warmer for seasons to come [9]);

- sweater - cable-knit, crewneck, roll-neck, $V$-neck, patchwork (e.g., Not only will the right crewneck sweater keep you cozy inside of your borderline freezing home office $<\ldots>[9]$ );

- pants - cargo, cropped, drop-crotched, vast cut, pleated, skinny (e.g., You're going to wear cargo pants this fall. Or, you should. Yeah, yeah, we know, they've got a bad rap. But these cargo pants are not those cargo pants [16]);

- suit - double-breasted, natural fit (e.g., The double-breasted suit carries an air of formality and pride about it $<\ldots>$ [17]);

- trousers - extralarge, flared, high-waisted, slim, streamlined, wide-leg;

- shorts - relaxed, turn-up, tailored (e.g., <...> casual knitted ties, gingham shirts, sun hats and even a pair of tailored shorts for braver leg-bearers [18, p. 179]);

- cardigans - oversized, patchwork, sleeveless (e.g., Unfortunately, the wool patchwork cardigan by JW Anderson is now sold out. You can try your luck finding one on the resale market, but with such a popular piece that's now made even more popular, it'll be a tough task [19]);

- jacket - lapels (on the jacket), narrower cut (of the jacket sleeves), peaked-lapel, zip-up, sleeveless (e.g., and tailored sleeveless blazers and biker jackets proving quite the thing at Burberry, where the trend remained at its strongest [20]);

- parka-quilted, Y-3 (e.g., This black Y-3 parka does the basics of a parka jacket well [13]);

- hoodie - longline, zip-up (e.g., But pick the right one and the zip-up hoodie can prove transformative, instantly providing a dose of casual cool in the form of an easy on/off layer you can shed with impunity while your body futilely tries to reconcile its cozy internal temperature with the frigid weather outside [21]);

-jeans - rolled-up, slim-cut (e.g. Wear with a pair of caramel Bermuda shorts and a pair of male Mary Janes from Hereu on warmer days and with a pair of slim-cut white jeans and chi-chi Hermès loafers when the sun goes in [18]).

The modern fashion discourse offers creative, difficult and non-standard cuts so that men who wear them can express their individualities.

Colours and prints in male fashion discourse. Colours in the fashion discourse get specific attention, and colours which are considered to be trendy are changing from one fashion season to another. The fashion discourse often offers detailed descriptions of colours, prints, possible matches of them: Elsewhere, the palette mixes muted charcoal and olive brown, with pieces such as a utilitarian patch-pocket khaki shirt, alongside a comfortably oversized hoodie, plus heavily laundered T-shirts emblazoned with graphic prints [11, p. 119].

Nowadays, thanks to technology advances any hue or any colour can be offered to fashion followers in the fashion market. The analysis of the articles has enabled to single out 28 different colours that are considered to be fashionable to wear for men in the latest years, they are presented in the following table (see Table 2).

Table 2

Male basic colours and hues

\begin{tabular}{|c|l|l|}
\hline $\begin{array}{c}\text { Basic } \\
\text { colour }\end{array}$ & \multicolumn{1}{|c|}{ Its hues } & \multicolumn{1}{c|}{ Textual examples } \\
\hline \multicolumn{1}{|c|}{$\mathbf{1}$} & \multicolumn{1}{|c|}{$\mathbf{3}$} \\
\hline black & charcoal & $\begin{array}{l}\text { Elsewhere, the palette mixes muted charcoal and olive } \\
\text { brown [17, p. 119] }\end{array}$ \\
\hline green & - & $<\ldots>$ fluorescent green Racing Road Nikes to make people laugh [17, p. 119] \\
\hline grey & $\begin{array}{l}\text { dark-grey, light- } \\
\text { grey, metallic }\end{array}$ & $\begin{array}{l}\text { The grey suit is a men's tailoring mainstay that, compared to its black and navy sartorial } \\
\text { brethren, is oft associated with business [18] }\end{array}$ \\
\hline red & $\begin{array}{l}\text { burgundy, } \\
\text { maroon, russet }\end{array}$ & $\begin{array}{l}\text { You likely have black, navy, gray, and camel colored clothing on rotation for fall already. } \\
\text { That's great! They're a solid foundation for mixing in other rich colors to create a seasonly } \\
\text { appropriate outfit. High up on that list: maroon } \text { [22] }\end{array}$ \\
\hline
\end{tabular}


Continuation Table 2

\begin{tabular}{|c|c|c|}
\hline 1 & 2 & 3 \\
\hline white & cream & $\begin{array}{l}\text { Gentlemen, let us present the witnesses in the case for white jeans, because since the Sixties } \\
\text { they've never been far from the legs of the world's most stylish men }[17, \mathrm{p} .68]\end{array}$ \\
\hline yellow & sand & These pale yellow shorts are giving us serious "The Talented Mr Ripley" vibes $<\ldots>$ [20] \\
\hline brown & $\begin{array}{l}\text { caramel, dark- } \\
\text { brown, olive }\end{array}$ & $\begin{array}{l}\text { Basketball-short perforations give this otherwise classic caramel knit a little bit of edge } \\
{[17] ; \text { A pair of smartly cut brown leather loafers (penny or otherwise) from a heritage }} \\
\text { British brand such as George Cleverley }[11, \mathrm{p} .43]\end{array}$ \\
\hline purple & $\begin{array}{l}\text { lilac, } \\
\text { lavender, } \\
\text { soft-violet }\end{array}$ & $\begin{array}{l}\text { Lilac, lavender, soft violet - whatever you want to call this pastelly shade of purple, it's } \\
\text { sweeping menswear right now [20] }\end{array}$ \\
\hline blue & $\begin{array}{l}\text { indigo, light- } \\
\text { blue, pale-blue, } \\
\text { dark blue navy, }\end{array}$ & $\begin{array}{l}\text { That soft shade of blue is dying to be paired with a chocolate brown cotton suit [22]; } \\
\text { If you're spending good money on a suit, you'll want to reuse it. If this is a priority, navy } \\
\text { is best as it will look great on the day and transition nicely into almost any smart-casual } \\
\text { situation [7] }\end{array}$ \\
\hline
\end{tabular}

Nine out of eleven basic colours are considered to be fashionable and are advertised to wear, but still two are mostly ignored - orange and pink though they may be seen as a part of prints. Different prints become quite popular styling male items of clothes: Whether it's an official artist meets brand collaboration or a designer going bold with graphic prints, art-inspired patterns are big this season - and the busier the better [17, p. 175]. The prints of the clothes vary in styles and designs. One of the prints is flecked pieces of clothing. It is close to polka-dot, but the patterns are different sizes and are asymmetric. Another type of print is foliage. Foliage determines the leaf print. Geometrical patterns are popular for T-shirts and shirts. Sharp forms and figures add masculinity. The most popular types of prints are plaid, tartan and windowpane.

Herringbone coats, jackets, trousers and other items of clothes and striped trousers and shirts are considered to be stylish as well: The heat-dissipating cotton fabric has had its traditional blue and white stripes remixed in new colour combinations for all occasions [7, p. 43]. Finally, different patterns on the pieces of clothing are also a trend. The prints mentioned above are meant to make a difference. In modern fashion discourse it is recommended to be expressive: Take Barbour's Tattersall shirts, which are simply a must for every gentleman's wardrobe. Based on a pattern from Tattersalls horse market that dates back to 1766, they remain a timeless classic [17, p. 223]; Deep, dark blue is the most versatile suit colour a man can own. Go for a subtle pattern for added interest and amp up its formality by investing in a matching waistcoat [23, p. 115].

There are 33 different styles of clothes colouring including prints. Thus, colours amount to almost $70 \%$ of the clothes styling, while prints varieties equal to $30 \%$. That means that colours still prevail in fashion discourse describing latest trends for men, while bright prints have much less variations and tend to more humble patterns like stripes and plaid. Among colours only, the basic colours amount to $34,8 \%$,

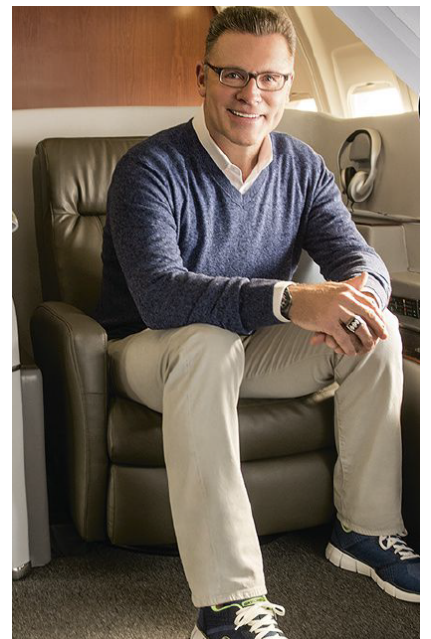

[19, p. 43]

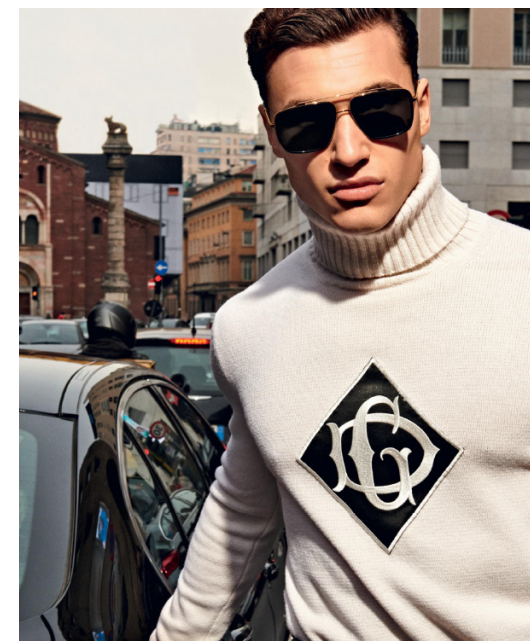

[10, p. 43]

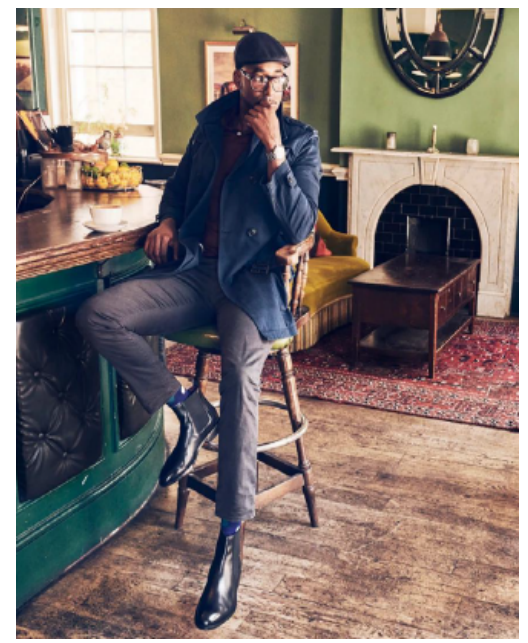

$[10$, p. 43]

Picture 1 
while the hues reach $65,2 \%$. Some colours in male fashion discourse are more popular and trendier. They are grey, having three fashionable hues, red, also having three fashionable hues, and blue with five hues that are the most popular among the male clothing pieces.

Images in fashion discourse. The analysis of photos in the two published magazines for men demonstrate that in general conventional gender portrayals are offered. Advertising of expensive brands quite expectedly includes pictures of successful men in the appropriate environment, either in a businessclass chair on the plane, or next to an expensive car, or in a luxury lounge, which is demonstrated in the photos given below (see Picture 1).

The history of a particular brand can be connected with an image of an adventurer, a sailor or just a hero, what can be seen on the picture below (see Picture 2).

Models are also traditionally tall, well-built, handsome, who wear clothes of traditional cuts and colours, which is demonstrated below (see Picture 3).

So, the masculinity image in the fashion discourse corresponds to tradional gender expectations, which can be partily explained by conservative style of the two magazines. Further research is going to

include the contrastive analysis of female fashion magazines discourse with the results obtained in the given study.

\section{The Original Montgomery, Since 1896}

\begin{abstract}
Montgomery first captured the nation's attention more than a century ago, when the company was selected by the Admiralty to make the first duffle coats.

Little has changed since then: Montgomery duffle coats are still tailor-made in England, and quality is still paramount — a philosophy that is as important today as it was when it made its first duffle coat.

Montgomery, the choice of heroes.
\end{abstract}

originalmontgomery.com

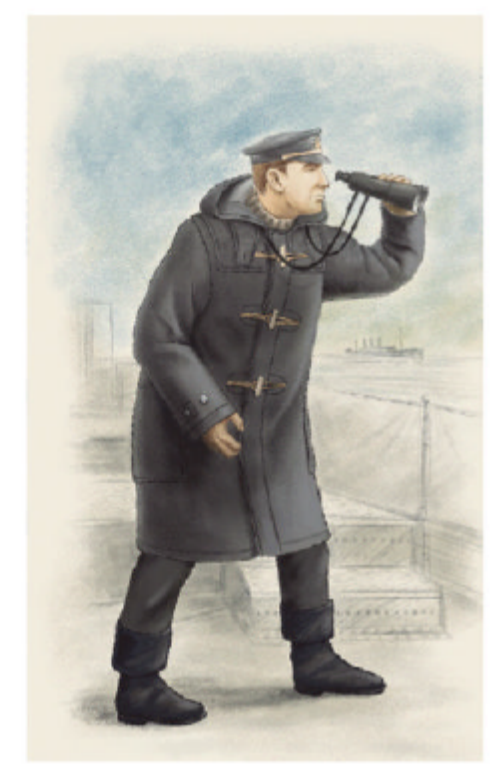

[12, p. 151]

Picture 2

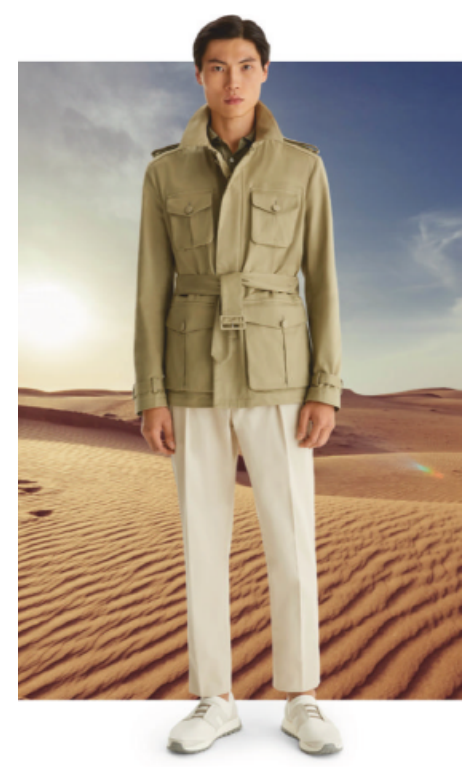

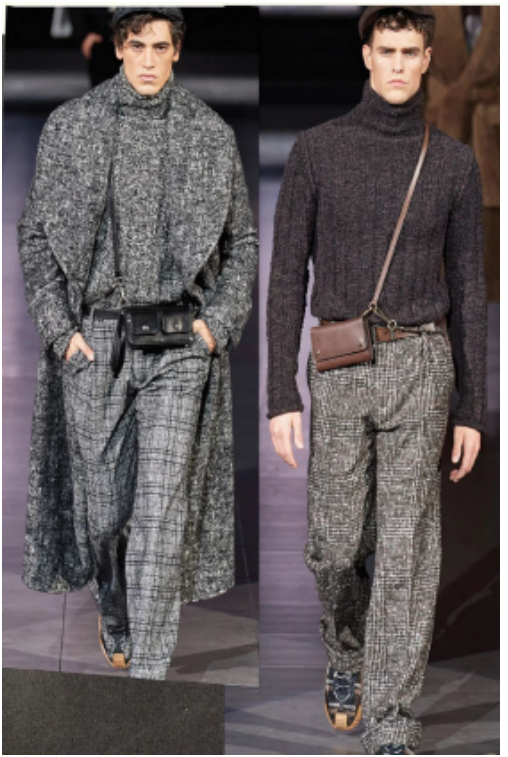

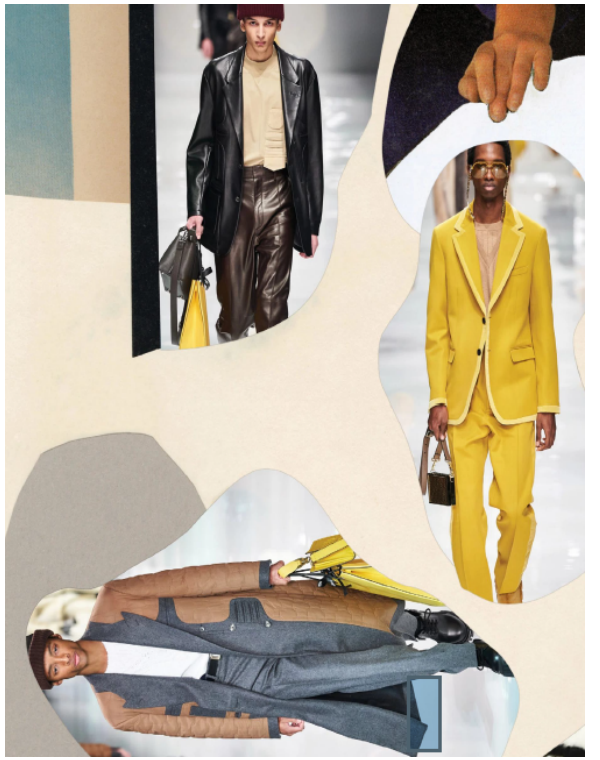

Picture 3

REFERENCES:

1. Jansen M. Fashion Anthropology: Challenging Euro Centricity in Fashion Studies. 2015.

2. Tjäder M. Discourse of Fashion Diffusion and National Fashion Identities in Luxury Fashion Firms' Webpage Communications. Copenhagen Business School, 2013.

3. Barthes R. The Fashion System. Los Angeles : University of California Press, 1990.

4. Hibbert C. The Twentieth Century. Hong Kong : Bailey Publishing Associates Ltd, 2005.

5. Hollander A. Sex and Suits: The Evolution of Modern Dress. London : Bloomsbury Publishing, 2016.

6. Twigg J. Clothing, identity and the embodiment of age. Aging and identity: A postmodern dialogue / J. Powell, T. Gilbert (Eds.). New York : Nova Science Publishers, 2009. P. 28-41. 
7. GQ, UK. Condé Nast International. 2017. Vol. 7. URL: https://www.gq-magazine.co.uk/fashion

8. GQ, USA. Condé Nast International. 2019. Vol. 3. URL: https://www.gq-magazine.co.uk/fashion

9. Esquire. New York : Hearst Communications, Inc. 2020. Vol. 8-9. URL: https://www.esquire.com/

10. Esquire. New York : Hearst Communications, Inc. 2019. Vol. 11-12. URL: https://classic.esquire.com/ issue/20191102

11. GQ, UK. Condé Nast International. 202. Vol. 6. URL: https://www.gq-magazine.co.uk/fashion

12. Esquire. New York : Hearst Communications, Inc. 2021. Vol. 5. URL: https://www.esquire.com/

13. GQ, UK. Condé Nast International. 2019. Vol. 9. URL: https://www.gq-magazine.co.uk/fashion

14. Esquire. New York : Hearst Communications, Inc. 2021. Vol. 2. URL: https://www.esquire.com/

15. Esquire. New York : Hearst Communications, Inc. 2020. Vol. 3. URL: https://classic.esquire.com/ issue/20200301

16. Esquire. New York : Hearst Communications, Inc. 2018. Vol. 8. URL: https://classic.esquire.com/ issue/20181101

17. GQ, UK. Condé Nast International. 2017. Vol. 10. URL: https://www.gq-magazine.co.uk/fashion

18. GQ, UK. Condé Nast International. 2018. Vol. 6. URL: https://www.gq-magazine.co.uk/fashion

19. Esquire. New York : Hearst Communications, Inc. 2017. Vol. 4. URL: https://classic.esquire.com/ issue/20170401

20. GQ, UK. Condé Nast International. 2020. Vol. 3. URL: https://www.gq-magazine.co.uk/fashion

21. Esquire. New York : Hearst Communications, Inc. 2021. Vol. 1-2. URL: https://www.esquire.com/

22. Esquire. New York : Hearst Communications, Inc. 2017. Vol. 10. URL: https://classic.esquire.com/ issue/20171001

23. Esquire. New York : Hearst Communications, Inc. 2020. Vol. 12. URL: https://www.esquire.com/

УДК 81'42: 616-036.211

DOI https://doi.org/10.32782/tps2663-4880/2021.18.29

\title{
КОНЦЕПТ «ПАНДЕМІЯ» В АНГЛОМОВНОМУ ЛІНГВІСТИЧНОМУ ПРОСТОРІ
} THE CONCEPT OF "PANDEMIC" IN THE ENGLISH LANGUAGE LINGUISTICS

\author{
Шарапановська Ю.В., \\ orcid.org/0000-0002-5397-2941 \\ аспірант кафедри романо-германської філологї̈ та методики викладання іноземних мов \\ Міжнародного гуманітарного університету
}

\begin{abstract}
Термін «концепт» у сучасній лінгвістиці є досить широким і неоднозначним. «Концепт» входить до термінологічного апарату багатьох наук та галузей знать, кожна з яких розуміє під «концептом» щось своє. У лінгвістиці терміни «поняття» та «концепт» протягом тривалого періоду вживались як синонімічні, нині здебільшого ці терміни розрізняють. Більшість сучасних мовознавчих підходів до розуміння поняття «концепт» зводяться зазвичай до лінгвокогнітивного та лінгвокультурологічного тлумачення цього явища. Незалежно від типів концептів, усі вони є структурними ланками, будівельним матеріалом концептосфери окремої мови, у якій можна виділити менші утворення. Безперечним для всіх підходів $€$ те, що концепт належить до свідомості і включає, на відміну від поняття, не лише описово-класифікаційні, а й чуттєво-вольові й образно-емпіричні характеристики. Концептосфрера охоплює собою всі сфери життя людини: концептами можна не лише мислити, але їх можна переживати. Під час вивчення концептів, що $є$ одиницями ментального рівня і не підлягають безпосередньому спостереженню, учені звертаються до плану вираження: слова, словосполучення, речення, тексту. Слово як ім'я концепту своїм лексичним значенням відображає найсуттєвіші ознаки концепту. Структура концепту представлена трьома базовими компонентами: образом, інформаційним змістом та інтерпретаційним полем. У статті надається спроба класифікації елементів концепту «пандемія», яку реалізовано завдяки комплексної методики дослідження концепту «пандемія» ("Pandemic") в англійській мові через поєднання загальнонаукових та лінгвістичних методів, що ґрунтуються на принципі системності вивчення об'єкта, що передбачає застосування поетапного аналізу мовного матеріалу. Мова, будучи соціальним явищем, завжди серед перших відображає зміни в будь-якій сфері людського життя; концепт «пандемія» уважається соціально важливим, особливо в поточній ситуації. Це ключовий елемент, включений нині в лінгвістичну картину світу майже кожної мови. Цей концепт складається з величезного та найважливішого психічного утворення в наївній та національній мовленнєвій картині світу.
\end{abstract}

Ключові слова: концепт, пандемія, ядро, периферія, лексико-семантична група, когнітивні ознаки. 